\title{
A Comparison of Organizational Commitment and Job Burnout among Teachers in Private and Public Institution with moderating effect of Job Satisfaction
}

\author{
Hasnain Sajid \\ Foundation University, Islamabad
}

\begin{abstract}
The research was designed to conduct a comparison between organizational commitment,and job burnoutamong faculty/teachers in privateinstitution and publicinstitution with a moderating effect of job satisfaction. A total of 107 responses were gathered through primary sources for the analysis of the study. Analysis was done using Multiple Regression.
\end{abstract}

\section{Introduction}

In today's world, organizations are eager to make the best use of productivity and efficiency by minimizing stress and exhaustion among their employees. Due to increased level of stress, burnout and exhaustion it is difficult for employees to maintain their high performance which eventually leads them towards condensed job satisfaction, and lesser organizational commitment. The situation is complex as it is more common that most of the times employees blame their organizations and jobs to be the reason behind their stress and burnout. Whereas, on the other hand, organizations blame employee to be responsible for their own stress and burnout. Most of the professions arewilling to work on and are more associated to burnout than others.Existing investigative studies commences their exams to identify burnout among teachers in public sector institutes and private sector institutes. These institutes believes it to be an essential part for the success of their educational system but due to dissatisfaction and burnout, the teachers of public and private sector institutes are not able to enhance their performance. It is globally believed and being practiced that organizational commitment is an essential factor for retention and attraction of well qualified employees, whereas only those employees who are satisfied from their job will be committed and will be willing to stay with their organization to make considerable struggle to achieve their objectives and goals.

In the previous years, organizational commitment has been believed to be a subject that is studied comprehensively in expressions of its mechanisms, backgrounds, associates, and significances. From various sources, it has been concluded that organizational commitment is an emotional affection to an organization. The reason to measure organizational commitment is to identify what employees think and feel about their workplace and how the organization can make itself as a more comfortable place for work so employees would become more attracted towards the organization. There are many reason that leads an employee to be committed to the organization, such as liberation, protection, gratification and distribution of authority.

Meyer and Allen (1997) identified that organizational commitment comprises of three modelsthat are'affective', 'continuance', and 'normative commitment'. First model is affective commitment; thatshows the level to which an employee identifies with his/her organization. If an employee is affectively committed, he / she will intensely accept the goals and challenges of his/her organization and will be motivated to stay as a portion of that organization. Whereas, normative commitment states that an employee may believe that he/she should remain committed with his organization and is influenced by the norms of his/her society. In continuance commitment, it states that employee will continue his work for the organization due to his / her individual's need and he will work for any organization based on anapparent costs linked. All these models have their own suggestions about the question that why employee stay with their organization, and as a summary I has been concluded that the employee may stay due to any of one reason i.e. because they want to stay; because they are influenced by the norms of their society; and because they need to for a cost.

According to Popoola (2006), personal factors (such as; age, marital status, gender, faith, professional experience, professional and academic education) has an effect on organizational commitment in Nigerian-state educational institutes. In a study, Opayemi (2004) and Angle and Perry (1981) have highlights in their studies about a momentous relation that exists between sex and organizational commitment of employees who work in public sector; which concluded that women are more dedicated than man towards their work.

Previous empirical evidences have suggested that the levels of dedication may rise (Sturges et al., 2005) or fall (Bambacas and Bordia, 2009) with the startof an appropriate career management. Moreover, Mathieu and Zajac (1990) have suggested that differences in these models of commitment may arise from differences between employees i.e. organizational commitment only depends on employees and how they value 
to their organizational offerings. (Offerings may include career opportunities, succession planning, and continuous improvement etc.). If any employee gives value to any of the offering, he / she may enhance their level of commitment. It is believed that organizational commitment plays a critical role in retaining and attracting highly qualified and competent resources in an organization.In a study, Mathieu (1991) and Ostroff (1992) have mention job satisfaction to be considered as one of the most indispensable component in organization performance. If the employees are satisfied with their job, it would be possible for the employees to give much better performance than they could give than being dissatisfied from the job.

It has been concluded in various studies from the past that employees' mays experience either a level of satisfaction or dissatisfaction on their job but it may vary from job to job, as there may be few aspects of the job that are more satisfying than others. Baron (1986) and Maghradi (1999) believe that employees' may feel satisfied from their job due to various other aspects that may be productivity, turnover rates, intention to quit and efficiency.

In last few years, organizational commitment in public and private sector institutes has become a major problem in Pakistan and other countries. Due to this problem, sufficient and considerable increased has been observed in policies and procedures which aim to highlight this problem.

\subsection{Problem Statement}

This study investigates the effect of burnout on organizational commitment on teachers of private institution and public institution and the effect of increased job satisfaction on organizational commitment among faculty (teachers) of the twin cities i.e. Rawalpindi and Islamabad toward their institutions.

\subsection{Objectives of the Study}

The research will carry out the study:

i. To find how job burnout effect organizational commitment and job satisfaction on the faculty (teachers) of private sectorinstitutionsand public sector institutions.

ii. To identify the liaison between job burnout and organizational commitment.

iii. To study the relationship of job burnout, job satisfaction and organizational commitment.

iv. To inspect the moderating effect of job satisfaction between job burnout and organizational commitment.

\subsection{Significant of Study}

This study is an attempt, which designed to investigate the relations of job burnout and organizational commitment keeping job satisfaction as a moderating element among teachers in public sector institutions and private sector institutions. This study is an effort to build up and to analyze a standard for burnout, determine its effect on job satisfaction and to identify job satisfaction's consequent effect on organizational commitment. By conducting this study we can also understand how public and private sector institutions' faculty (teachers) can become happy and show their commitment towards their organization and how much does these different aspects have an contribution towards their level of commitment. It can play a vital role in heighten up their performance.

\section{Literature Review}

Organizational commitment has been define as a psychological attachment of an employee with the organization, that can be measured by different indicators such as loyalty, dedication and commitment (Cook and Wall, 1980; Lambert, 2003; Mowday et al, 1979). Mowday et al. identifies four dimensions of the organizational commitment. These are work experience, role, structural, personal characteristics. Kobasa, (1982) and Antosnovsky (1979) defines that organizational commitment is the key to avoid the negative behaviors of any employee. Employee feel more committed towards their organization if they have the feeling that their work is meaningful for the organization. Burke and Greenglass, (1989) found in their study that there are few personality traits that are positively correlated with the job burnout. And the factors that have consistently positive impacts on the job burnout are work settings, peers coordination and appropriate level of supervision. The employee who is strongly committed to the organization can clearly define the organization's goals and affectively implement these goals. Any employee who is committed to the organization is definitely having emotional attachment with the organization. Continuous commitment develops out of the perceived cost (cost benefit analysis) by the employees regardless of the effects on the organizations end. Normative commitment is that the employee is loyal and dutiful because he/she thinks that this is the right thing to do that's why committed to the organization (Meyer and Allen, 1997). In every organization every employee under goes by the process called internalization in which they understand the norm, values and the expectation of the organization. Organizational commitment has a significant relationship with job satisfaction, job involvement, stress, occupational commitment, motivation (Katchand and strawser, 2000). Koopman (1991) identifies in a 
study that those employee who are favored by the managers are more accepted by the organization and are more committed to the organization. Lower level of commitment create dilemma that can adversely affect the organization as well as on the employee and leads to the employees less successful in their professional performance (Clepe, 2000). Job stress has significantly worst effects the on physical health, psychological well and work performance of the employee (Kahn and Byosiere, 1992; Souter and Murphy, 1995).

Three main factors that leads to the job burnout are depersonalization reduce personal accomplishment and emotional exhaustion and due to the factors the job burnout leads to the job dissatisfaction. This phenomenon is affected by the gender mostly females are more satisfied by their job as compared to the men and in return their expectation about the job status is low. The employees who suffer from the job stress are unable to perform his/her functions effectively. The negative outcomes of the job stress are high level of absenteeism, high turnover rate, low productivity, staying quit becomes the nature of the employee and this would affect the overall well-being of the employee (Baron, 1986; Maghradi, 1999). Higher work pressures are the outcome of the globalization (Nixon 1992). When employee is suffering job burnout then it is quite possible that he/she might undergo with several physical and emotional exhaustion which would have negative effect on the work attitude and is not the matter of concern for others (Handy 1988). Role conflicts in certain situations are also the reason for the job burnout (Rizzo, House and Lirtzman 1970). Role conflict is the role ambiguity that refers to the not clear understanding about the behaviors that are required for the certain position and are mismatch with the established standards and behaviors (Rizzo et al., 1970). Time is another factor that has a significant impact on the job stress, when employees are with task and the deadlines to meet and if the deadlines are not that much that an employee can easily and utilizing his/her full potential can complete them then definitely they feel psychological burden which would reduce their performance and they become unable to meet the deadline which ultimately become the reason for the job stress and job burnout for the employees (Srinivas and Motowidlo, 1987). Work life balance is another key factor that has a positive impact on the employee performance (Duxbury and Irving, 1992). Some advantages identified by most of the researcher are increased performance, lower tiredness, less job stress and job dissatisfaction (Rainey and Wolf, 1982). By reviewing the literature we come to know that organizational commitment has a positive impact on performance (Aranya, Kushnir and Valency, 1986) negative effect on turnover and turnover intentions (Mathieu and Zajac, 1990; Porter, Steers and Mowday 1974).

Gender play an important role in the level of job satisfaction females are mostly comfortable and have psychological commitment developed if they find flexible timing of the working hours as their first preference is their home and family duties in addition to their full time employed (Hoschild 1989; Bielby and Bielby 1988). Therefore the feeling that organization care for them increases their performance and the organizational commitment (Rousseau, 1995). Some important facts that are identified by most of the researcher to study organizational commitment are Leadership bhaviour (Tatlah et al., 2011), job satisfaction (Salami, 2008) and burnout (Gemlik et al., 2010). Employees who have higher organizational commitment are happier with their work, cannot stay unconnected from their jobs and have lesser intention to leave the organization (Mowday et al., 1979). Opposite to the previous situation if employees are less committed they are fed up from their jobs, emotionally exhausted and they are more intended to leave the organization as soon as they find any opportunity (Celep, 2000). The resons that most of the researcher identified for the organizational commitment are almost the same, such as low absenteeism, high work efficiency and performance, low turnover etc. but the fact is that there as some psychological issues that play the key part in increasing or decreasing the organizational commitment, they are emotional exhaustion, job stress, work life imbalance, economic flaws etc. by addressing these factors along with the typically addressed phenomena will create a great difference and it would give a concrete model of study for the organizational commitment.

Hence, the proposed research model can be applied to examine the influence of Burnout on Organizational Commitment with the mediating role of Job Satisfaction.

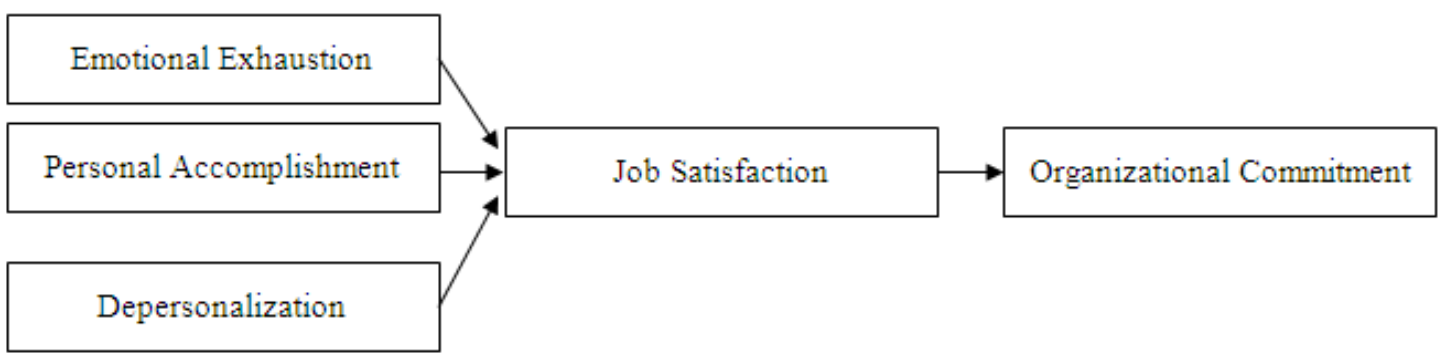

Following hypothesis are concluded through the theoretical framework:

H1: A negative relationshipsubsists between job satisfaction and emotional exhaustion.

$\mathrm{H} 2$ : A negative relationshipsubsists between job satisfactionand personal accomplishment. 
H3: A negative relationshipsubsists between job satisfactionand depersonalization.

H4: A negative relationshipsubsists between organizational commitment and emotional exhaustion.

H5: A negative relationshipsubsists between organizational commitment and personal accomplishment.

H6: A negative relationshipsubsists between organizational commitment and depersonalization.

H7: In the relationship of organizational commitment and depersonalization, job satisfaction has a mediating effect.

H8: In the relationship of organizational commitment and emotional exhaustion, job satisfaction has a mediating effect.

H9: In the relation of organizational commitment and personal accomplishment, job satisfaction has a mediating effect.

\section{Research Methodology}

To conduct this research, data has been collected through primary sources i.e. Questionnaire. It was designed on afive likert scale that consist a total of 64 items. Furthermore, data has been collected from 107 respondents of public sector institutes and private sector institutes. Maslach Burnout Inventory (MBI) of Maslach and Jackson (1986) has been used to measure the burnout.Maslach and Jackson has developed the scale to measure burnout by using 3 sub-scales those are depersonalization, personal accomplishment and emotional exhaustion. Job satisfaction was measured through Minnesota Satisfaction Questionnaire (MSQ) which has been used to measure job satisfaction among faculty (teachers) in public sector institutes and private sector institutes. Whereas, organizational commitment was measured on 18 items scale of Meyer, Allen and Smith (1993).

\section{Data Analysis and Discussion}

Table 4.1 Multiple Regression Analysis

\begin{tabular}{|c|c|c|c|c|c|c|c|c|c|c|c|c|}
\hline & \multicolumn{3}{|c|}{ Job Satisfaction } & \multicolumn{3}{|c|}{$\begin{array}{c}\text { Organizational } \\
\text { Commitment }\end{array}$} & \multicolumn{3}{|c|}{ Job Satisfaction ${ }^{\star}$} & \multicolumn{3}{|c|}{$\begin{array}{l}\text { Organizational } \\
\text { Commitment }^{\star}\end{array}$} \\
\hline & Beta & $\mathrm{T}$ & $\mathrm{p}$ & Beta & $\mathrm{t}$ & $P$ & Beta & $\mathrm{t}$ & $\mathrm{p}$ & Beta & $\mathrm{t}$ & $\mathrm{p}$ \\
\hline $\begin{array}{l}\text { Emotional } \\
\text { Exhaustion }\end{array}$ & -.262 & -3.08 & .001 & -.032 & -.322 & .748 & $\star \star *$ & ** & ** & $\star \star$ & 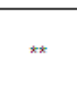 & 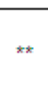 \\
\hline $\begin{array}{l}\text { Personal } \\
\text { Accomplishment }\end{array}$ & -.484 & -5.80 & .000 & -.255 & -2.76 & .007 & -.047 & -.464 & .644 & -.442 & -4.340 & .000 \\
\hline Depersonalization & -128 & -2.01 & .008 & -.258 & -2.62 & .021 & -.445 & -5.31 & .000 & -.256 & -3.053 & .003 \\
\hline
\end{tabular}

*mediation analysis values

**no mediation due to the failure of pre-requisites to run mediation

Table shows that Hypothesis 1 of our study is true that a negative relation subsists between emotional exhaustion and job satisfaction ( $\mathrm{t}=-3.08, \mathrm{p}<.05)$. Hypothesis 2 of our study is also true that a negative relationship do subsist between persona accomplishment and job satisfaction $(t=-5.80, \mathrm{p}<.05)$ through the regression analysis as shown in table 4.1. Hypothesis 3 of this study proved to be true that a negative relationship subsistsbetween job satisfaction and depersonalization $(t=-2.01, p<.05)$. Hypothesis 4 was found false because results showed that no relationship subsistsbetweenorganizational commitmentand emotional exhaustion ( $p>0.05)$. Hypothesis 5 and 6 found true as results of table showed that a negative relation subsists among personal accomplishment, organizational commitment and depersonalization.

Referring to table 4.1, none of the mediators had any effect on the depending variable. Thus, test could not established for Hypothesis 7,8 and 9 of the study which stated that job satisfaction mediates an effect of emotional exhaustion, personal accomplishment and depersonalization on organizational commitment, as no significant effect was found of mediating variable on the dependent variable.

\section{Conclusion}

Main idea behind this study was to inspect the relationship of burnout on organizational commitment concerning teachers of the public and private sector educational institutes. This study concluded that:

- Emotional exhaustion, personal accomplishment and depersonalization were not established relationship with organizational commitment. As condition of mediation did not applied therefore, themediation test was not applicable on this relationship.

- Burnout negatively effects the organizational commitment of teachers. 
- It was also determined by the analysis that lead to attain results that there is significant negative affiliation between satisfaction of faculty (teachers) andburnout.

\section{References}

[1]. Angle, H. L. \& Perry, J. L. (1981) "An empirical assessment of organizational commitment and organizational effectiveness". Ithaca, NY: Cornell University.

[2]. Bakker, A.B., Demerouti, E. \&Euwema, M.C. (2005) "Job resources buffer the impact of job demands on burnout. Journal of Occupational Health Psychology", 10(2), 170-180.

[3]. Brissle, J. (1988) "Individual situational contributors to teacher burnout. The Journal of Educational Research", 82(2), 106-112.

[4]. Brayfield, A.H. \& Crockett, W.H. (1955)“Employee attitudes and employee performance. Psychological Bulletin”, 52(5), 396-424.

[5]. Chapman, D. W. \& Green, M. S. (1986) “Teacher retention: Afurther examination. Educational Research”, 79(5), 272-278.

[6]. Cropanzano, R., Rupp, D.E. \& Byrne, Z.S. (2003)“The relationship of emotional exhaustion to work attitudes, job performance and organizational citizenship behaviors. Journalof Applied Psychology”, 88(1), 160-169.

[7]. Kahn, R.L., Wolfe, D.M., Quinn, R.P., Snoek, J.D. \&Rosenthal, R. A. (1964) “Organizational stress: In role conflict and ambiguity". New York: Wiley.

[8]. Koeske, G.F. \&Koeske, R.D. (1989) "Construct validity of theMaslach burnout inventory: A critical view and reconceptualization".The Journal of Applied Behavioral Sciences, 25(2), 131-144.

[9]. Leiter, M.P. \&Maslach, C. (1988) "The impact of interpersonal environment of burnout and organizational commitment. Journal of OrganizationalBehavior", 9(4), 297-308.

[10]. Schwab, R.L. \&Iwanicki, E. F. (1982) "Perceived role conflict, role ambiguity and teacher burnout. Educational AdministrationQuarterly",18(1), 60-74.

[11]. Smith, P.C., Kendall, I.M. \&Hulin, C. I. (1969) "Measurement of satisfaction in work and retirement. Chicago, IL: RandMcNully.

[12]. Stremmel, A.J., Benson, M.J.\& Powell, D. R. (1993) "Communication, satisfaction and emotional exhaustion among childcare center staff: Directors, teachers and assistant professors".EarlyChildhood Research Quarterly,8(2), 221-233.

[13]. Torelli, J.A. \&Gmelch, W.H. (1993)“Occupational stress and burnout in educational administration”. People and Education,1(4), 363-381.

[14]. Wiener, Y. \&Gechman, A.S. (1977)“Commitment: A behavioral approach to job involvement”. Journal of VocationalBehavior, 10, 47-52.

[15]. Pearson, L.C. \&Moomaw, W., (2005). "The relationship between teacher autonomy and stress, work satisfaction, empowerment, and professionalism”. Educational Research Quarterly, 29(1), 38-54.

[16]. Meyer J.P. and Allen N. J. (1991)“A three-component conceptualization of organizational commitment. Human Resources Management Review". 1(1): 61-89.

[17]. Popoola S.O. (2006)“Personal factors affecting organizational commitment of records management personnel in Nigerian State Universities". Ife Psychologia. 14(1): 183-97.

[18]. Maslach, C., \&Leiter, M. P. (1997)“The truth about burnout”. San Francisco:Jossey Bass.

[19]. Jackson, S. E., \&Maslach, C. (1982) “After-effects of job-related stress: Families as victims. Journal of Occupational Behavior", 3, 63-77.

[20]. Kyriacou, C. (1987) "Teacher stress and burnout: An international review”. Educational Research,29, 146-152. 